$\begin{array}{llll}\text { Al-Rafidain Engineering } & \text { Vol.14 } & \text { No. } & \end{array}$

\title{
Application of Thermal Energy Storage Systems to Public Worship Buildings
}

\author{
Dr. Ghalib Y. Kahwaji \\ Assistant Professor \\ Department of Mechanical Engineering, University of Mosul-Iraq. \\ E-mail: ghalibkahwaji@yahoo.com.
}

\begin{abstract}
$\underline{\text { Abstract }}$
This paper presents the feasibility of utilizing thermal energy storage systems in reducing both the initial and running expenses of chiller systems in large mosques. The study focused on the great mosque in the city of Mosul as a model. Two load profiles are considered, the occasional and the normal profiles with three different partial storage control strategies. The conventional strategy is also considered for the purpose of comparisons. From the results, it can be concluded that, the amount of the shifted load from the on-peak period for the occasional profile is equal to $45.2 \%, 24 \%$, and $39.1 \%$ for the three control cases respectively. Up to $74 \%$ reduction in the on-peak power consumption can be achieved with a total shifted power, (from the on-peak to the off-peak periods) of up to $47.2 \%$, which will add significantly to the total cost reduction. For the normal profile, the amount of the shifted load from the on-peak period is equal to $9.8 \%$. The peak power consumption is reduced by $33.1 \%$, and about $10 \%$ of the consumed power is shifted to low price period.
\end{abstract}

Key words: $\mathrm{A} / \mathrm{C}$ systems, refrigeration systems, thermal energy storage.

$$
\begin{aligned}
& \text { تطبيقات أنظمة الخزن الحراري في أبنية العبادة العامة } \\
& \text { الدكتور غالب يونس قهوجي }
\end{aligned}
$$

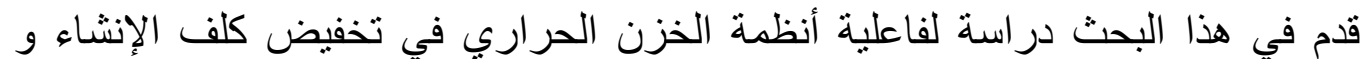

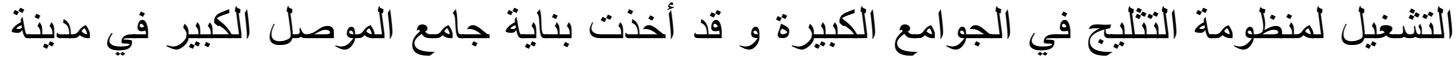

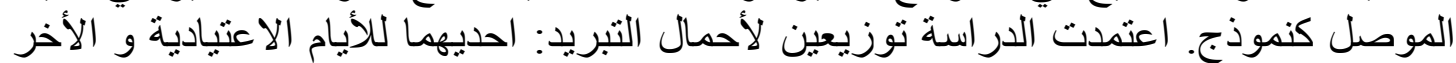

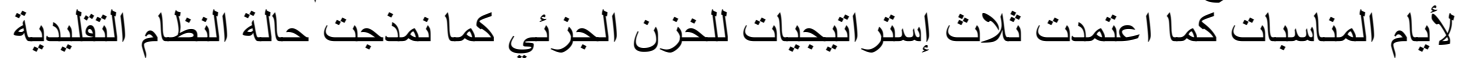

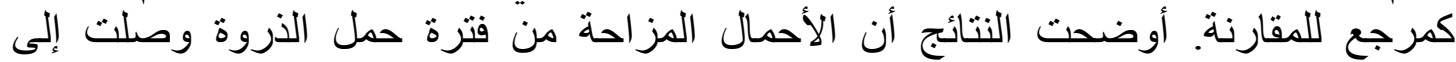

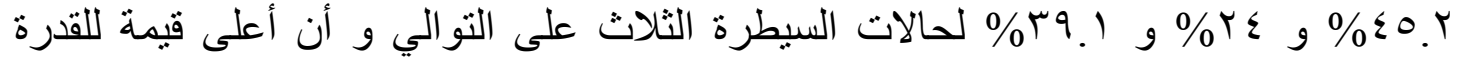




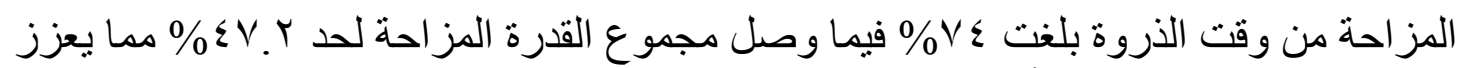

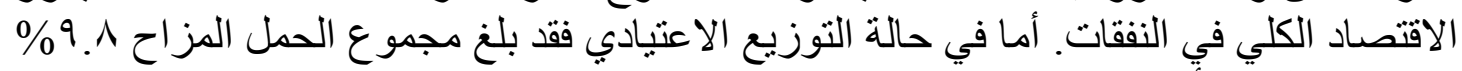

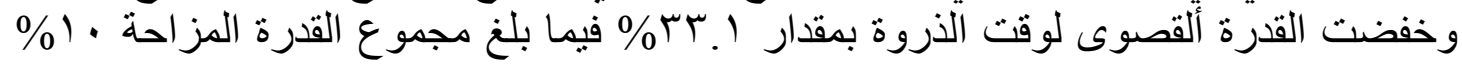

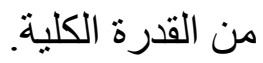




\section{Introduction:}

Thermal Energy Storage (TES) systems have the reputation of saving operating cost for cooling systems by appropriately utilizing the time-ofuse (TOU) incentives in the utility rate structure. Such systems are applicable in most public, commercial and industrial facilities when ever the maximum cooling load is much higher than the average load and/or when the on-peak and off-peak electricity prices are significantly different. Many applications have been reported in public schools, stores and military facilities where they proven beneficial, [1,2,3, and 4].

In general, two contradicting effects influences the operation of TES systems: the first is the increase in the coefficient of performance (COP) of the chiller due to working at design capacity during cool night hours and, the second is the increase in consumed power due to the subfreezing evaporator temperature during the ice making mode, [5]. The ice storage heat loss to the environment is another drawback that causes the TES system to consume more electricity than conventional systems, [5]. However, with careful controls this can be overcome. It has been shown that storage priority control strategies can save up to $45 \%$ in the overall operating cost, [2].

In large public worship places, such as big mosques, TES systems are believed to have great saving potential. The electricity cost can be reduced through proper demand side management (DSM). Moreover, the overall initial cost of the system is also cut down through reducing the size of the chiller as well as the supporting electrical supply system. For example, replacing a $500 \mathrm{TR}$ conventional chiller with a $250 \mathrm{TR}$ chiller and with its appropriate thermal storage modules can reduce the initial cost significantly since the chiller costs about $\$ 350 / \mathrm{TR}$ while the storage costs about $\$ 150 / \mathrm{TR}$; add to that the savings in the cost of the electric feeder which might amounts to about $40 \%$.

The present paper explains the results of incorporating a TES system in the air conditioning of large public mosques with the Great Mosque of the city of Mosul-Iraq as an example. The mosque is built over an area of $5000 \mathrm{~m}^{2}$ and can provide services for up to 7500 worshippers with a number of libraries, class rooms and lecture halls.

\section{The Building Load Profile:}

The peak cooling load of the mosque was estimated at $818 \mathrm{TR}$ during the month of August,[6]. This load is constituted approximately of $25 \%$ shell load and $75 \%$ internal and ventilation load at the peak time. Two load profiles were selected, a normal day profile that is based on partial occupancy which covers the normal - every day activities of such large building and, a busiest day profile (occasional profile) that covers 
the day of Friday in the month of Ramadhan where there are two periods during which the mosque is assumed to be fully occupied. The two periods covers the Friday prayer at noon and the period from Al-maghrib prayer to the end of Al-taraweeh prayer. Figure 1 shows the details of the suggested profiles.

\section{Load Management and Control Strategies:}

To arrive at the optimum system requires the knowledge of the power price structure, which should be realistic, as well as the other financial factors. Due to the lack of such information in our area, the decision was made to base the different systems comparisons on their thermal performance only.

As mentioned earlier, the DSM strategy as well as the system control strategy, (chiller or storage priority), affects the final performance of the system, [5]. Due to the presence of the continuous base load, (figure 1), the partial storage strategy with chiller priority was adopted in this work. In the chiller priority control, the chiller is allowed to operate at full capacity during the day, subject to the building load limitations. This type of control is simple and inexpensive since the original chiller control system can be left intact [7]. Four cases were studied; one represents the normal load profile and three for the occasional profile. The three differ by the refrigeration system capacity as shown in figure (2).

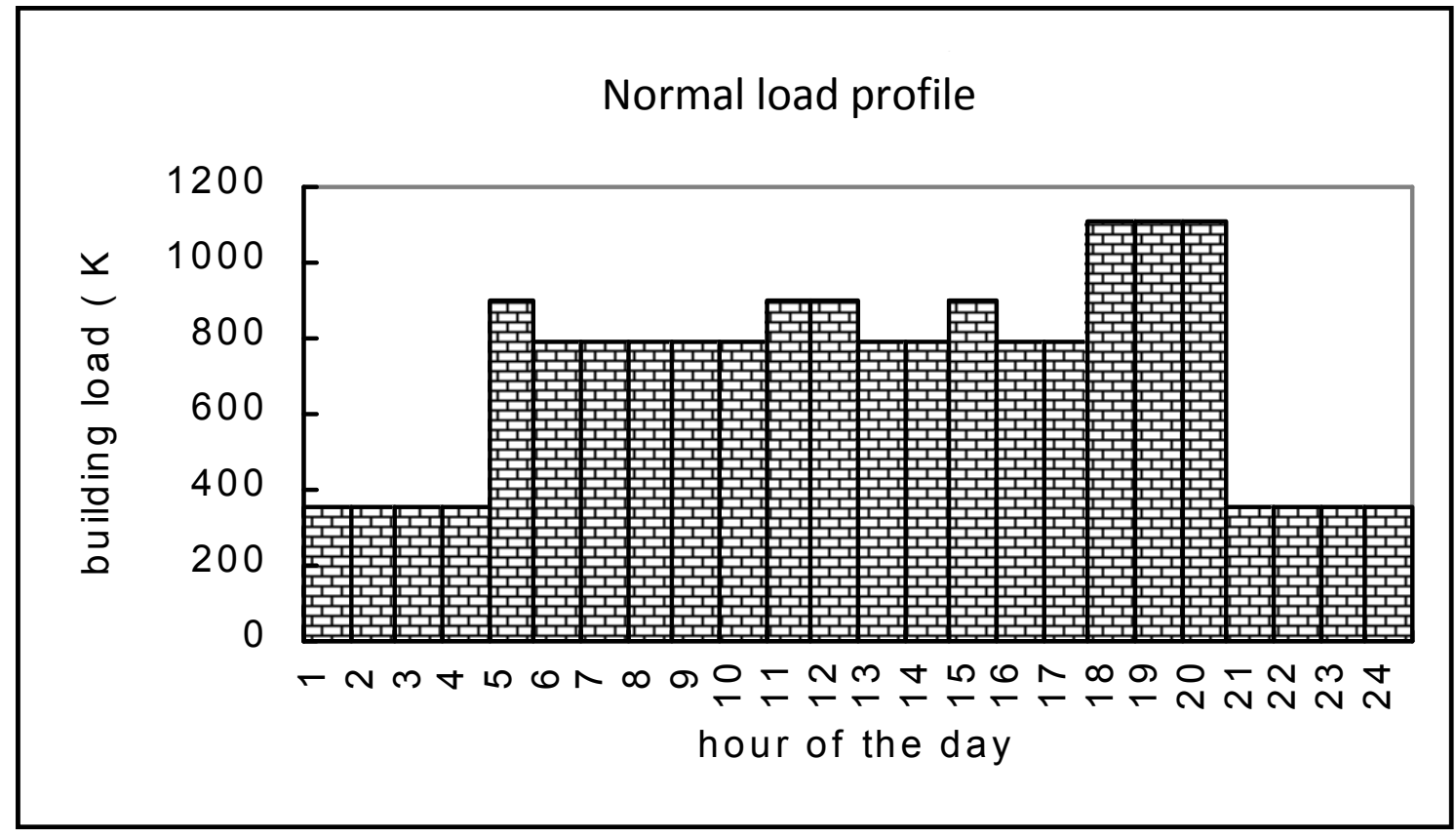

Occasional load profile

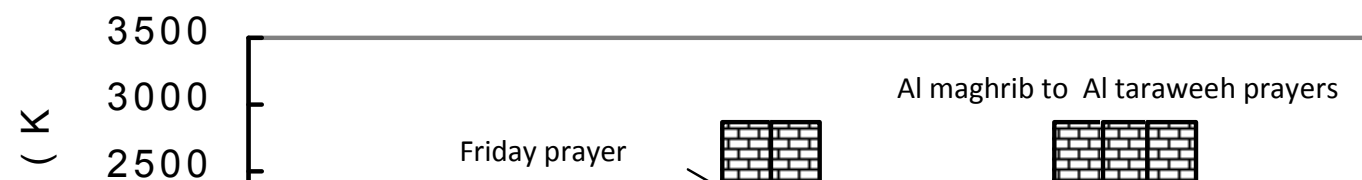




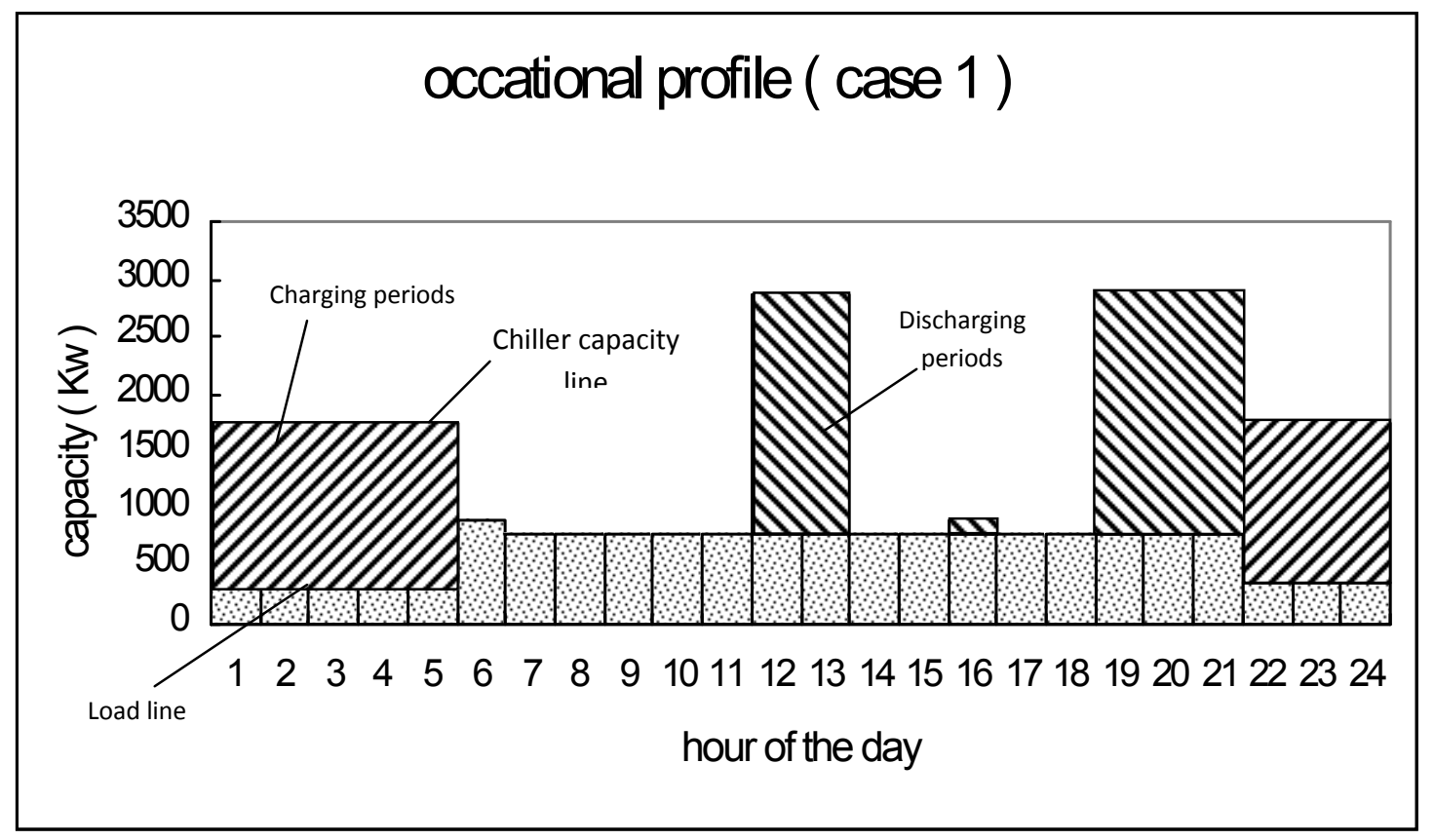

Fig (2-a ) : case 1 energy strategy.

chiller size $=500 \mathrm{TR}$, max. charging capacity $=500 \mathrm{TR}$,

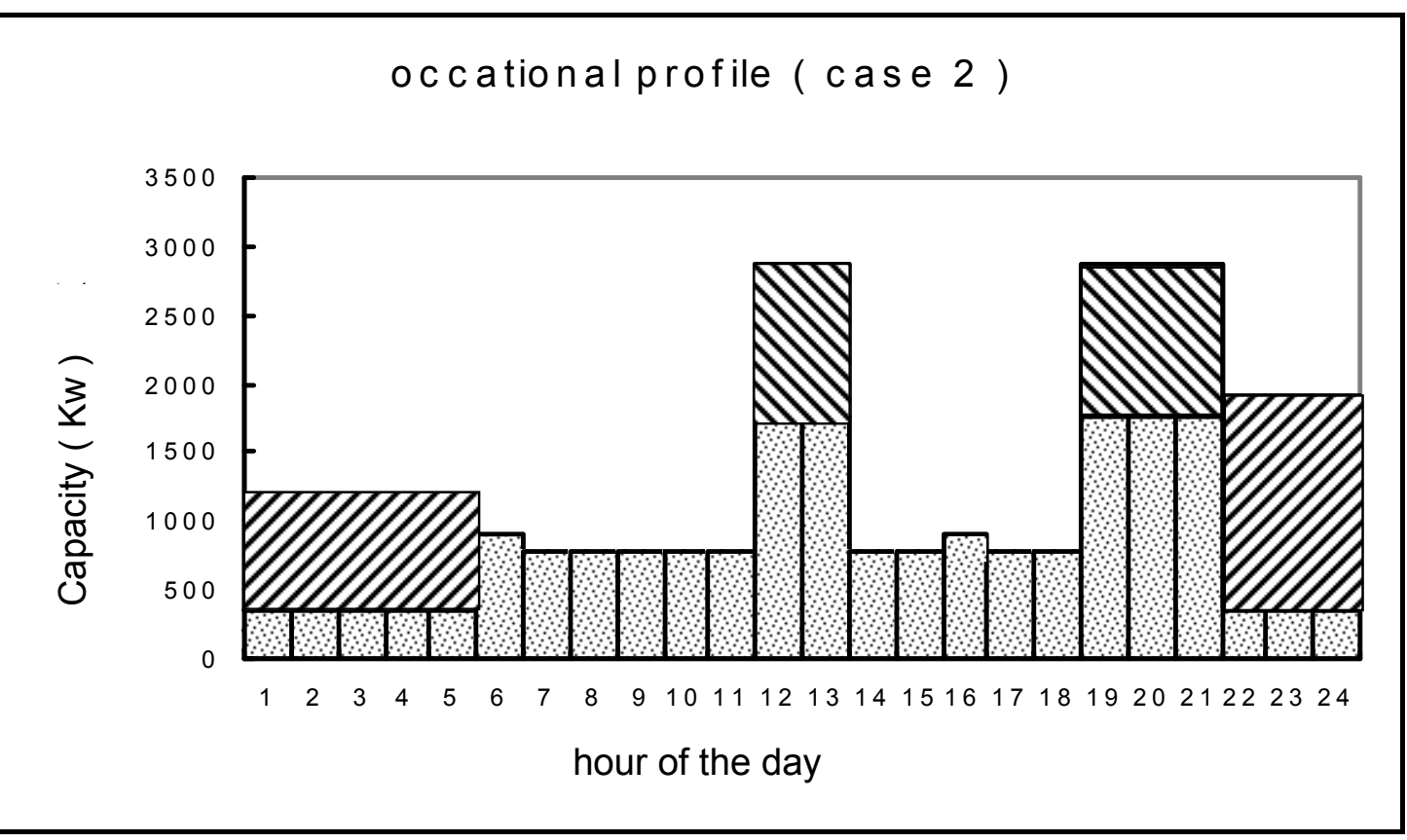

Fig (2-b ) : case 2 energy strategy.

chiller size $=500 \mathrm{TR}$, on- peak , max. chiller capacity $=500 \mathrm{TR}$, no. of storage modules $=125$. 


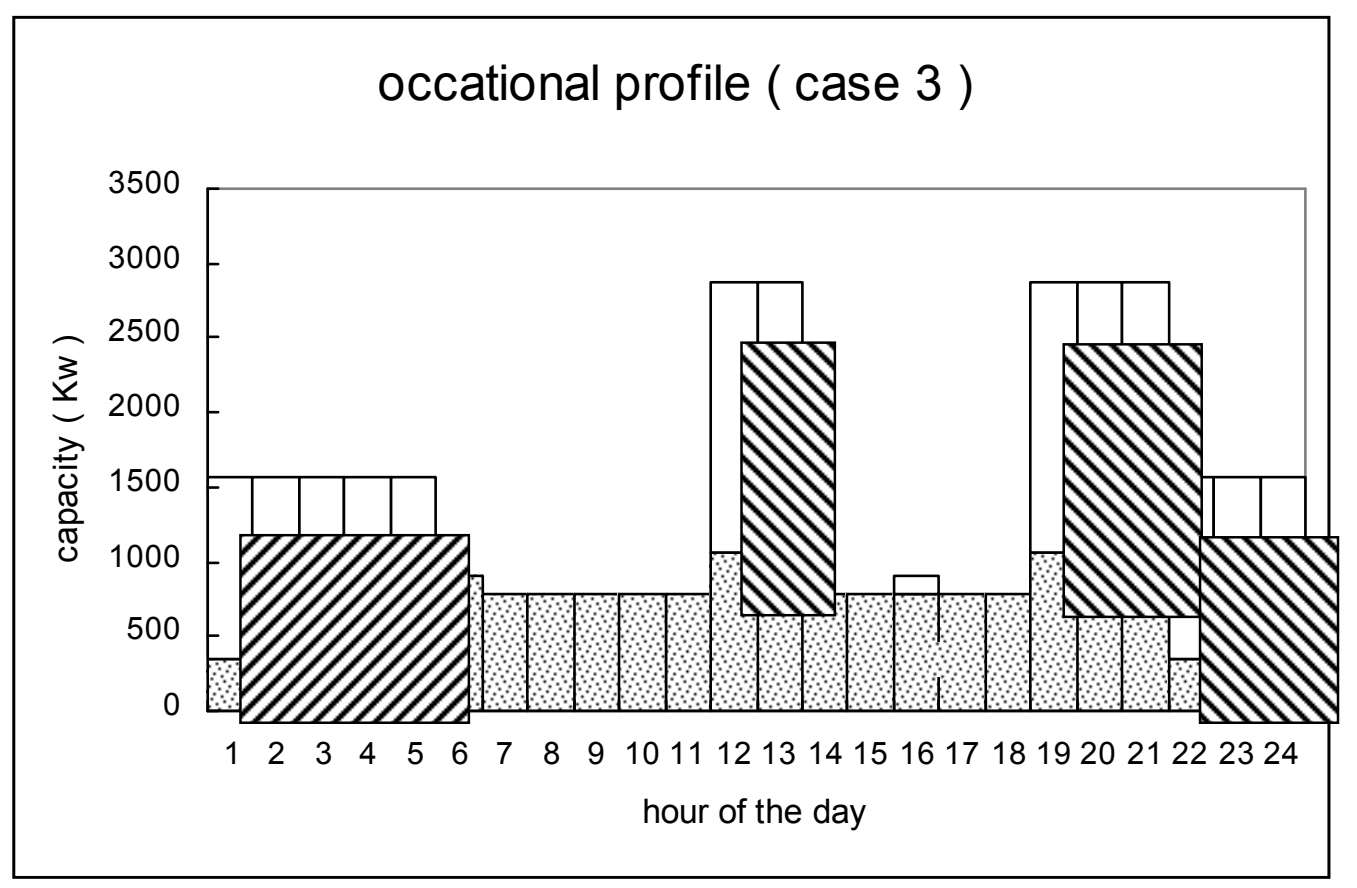

Fig (2-c ) : case 3 energy strategy.

chiller size $=500 \mathrm{TR}$, on- peak , max. chiller capacity $=300 \mathrm{TR}$, no. of storage modules $=204$.

\section{normal profile (case 4 )}

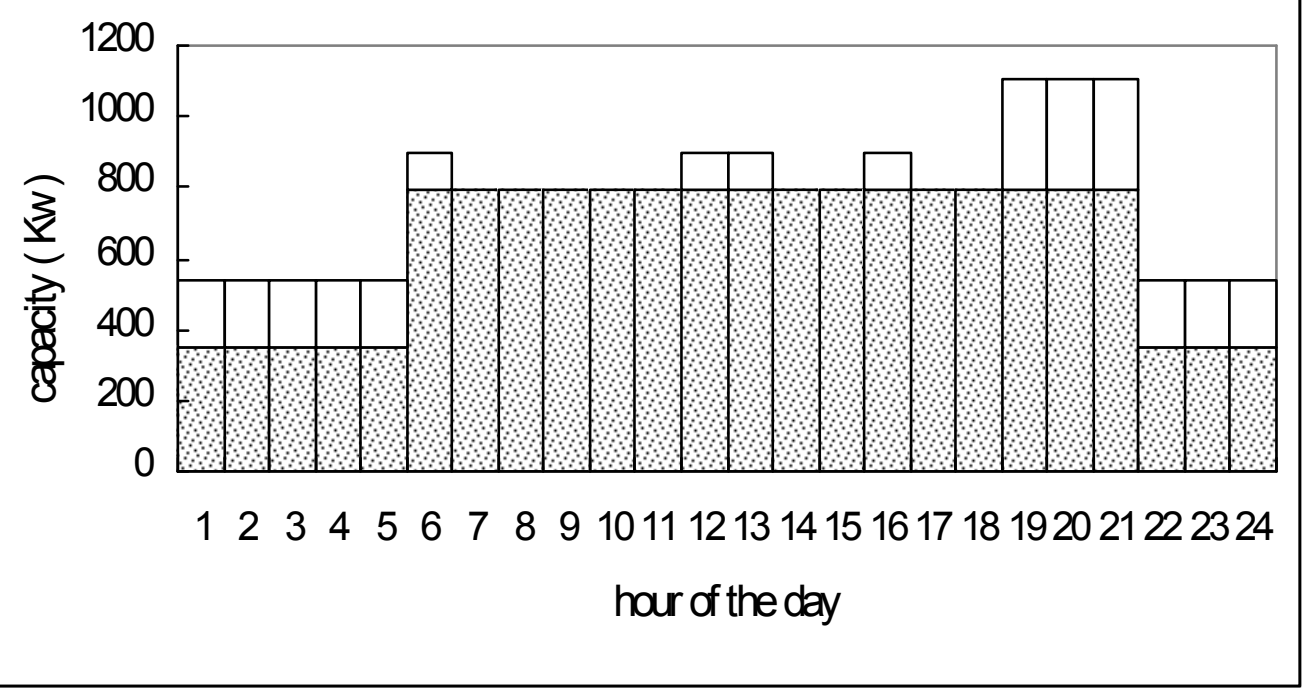

Fig (2-d ) : case 4 normal load energy strategy. on- peak, max. chiller capacity $=225 \mathrm{TR}$, 


Al-Rafidain Engineering $\quad$ Vol.14 No.r 2006

\section{The refrigeration system:}

The refrigeration system considered in this study consists of a reciprocating compressor, a water-chilling evaporator, a water-cooled condenser, chilled water and condenser water pumps and a cooling tower. Any simulation model must contain mathematical models for all of the above components. The curve fit procedure suggested by Mostafa [8], is applied to the manufacturer's data to obtain the required model because it gives better realistic estimation of the power consumption and capacity of the refrigeration systems. Under the partial storage strategy, the refrigeration system works at constant low evaporation temperature and constant capacity during the charging cycle. During the discharge cycle, the refrigeration system works at constant high evaporation temperature and at constant capacity approximately selected to suit the situation at hand. Note that, the refrigeration system capacity is not equal during the charge and the discharge cycles. Moreover, the number of working chillers will depend on the required capacity during the charge and the discharge cycles. All the chillers under service will operate at full load except the last one which will operate at partial load conditions. For the conventional operation of the refrigeration system, the exit coolant temperature from the chillers is fixed at $5.6{ }^{\circ} \mathrm{C}$. The exit coolant temperature from the air handling units is fixed at $11.6^{\circ} \mathrm{C}$. Accordingly, the evaporation temperature is constant if the capacity of the chiller is constant. Capacity control was achieved using the method of cylinder unloading. The ice storage system is comprised of a number of TES modules which were based on the study given by $[9,10]$. Table (1) lists the characteristics of such module.

Table (1): Details of the ice-storage module.

\begin{tabular}{|l|}
\hline Tank diameter $=1.065 \mathrm{~m}$ (without insulation). \\
\hline Tank height $=1.442 \mathrm{~m}$ (without insulation). \\
\hline Insulation type $=$ Glass wool $\left(\rho_{\text {ins }}=96 \mathrm{Kg} / \mathrm{m}^{3}\right.$ \\
$\left.\mathrm{K}_{\text {ins }}=0.0339 \mathrm{~W} / \mathrm{m}-{ }^{\circ} \mathrm{C}\right)$. \\
\hline Insulation thickness $=0.1524 \mathrm{~m}$. \\
\hline Rate of power input to the mechanical agitator $=75 \mathrm{~W}$. \\
\hline Heat exchanger plate length $=30 \mathrm{~m}$. \\
\hline Heat exchanger plate height $=1.292 \mathrm{~m}$. \\
\hline Number of turns of the heat exchange surface $=18$. \\
\hline Distance from center to center between each two turns $=$ \\
$0.029075 \mathrm{~m}$. \\
\hline Number of finned tubes in the heat exchanger $=11$. \\
\hline
\end{tabular}




\begin{tabular}{|l|}
\hline Tube diameter $=0.015875 \mathrm{~m}$. \\
\hline Fin length $=0.0508 \mathrm{~m}$. \\
\hline Fin thickness $=0.001 \mathrm{~m}$. \\
\hline Metal of fins $=$ Copper $\left(\mathrm{K}_{\mathrm{f}}=386 \mathrm{~W} / \mathrm{m}^{\circ} \mathrm{C}\right)$. \\
\hline Maximum ice thickness on one side of the heat exchanger $=$ \\
$0.0066 \mathrm{~m}$. \\
\hline Storage capacity $=168483.6 \mathrm{~kJ}=0.5545 \mathrm{TR}$. \\
\hline Average heat loss rate $=0.12432 \mathrm{~kW}$. \\
\hline
\end{tabular}

\section{System Arrangements and Full System Simulation:}

The arrangements shown in Figures (3-a to c) are used in this study. These arrangements are designed to be suitable for the above mentioned cooling load profiles. For more details see ref. [7,11, 12, and 13]. Figure (3a) illustrates the flow diagram of the charge cycle. This system operates as follows: at the start of the charge cycle the control system set the refrigeration systems to operate at constant low evaporation temperature and at constant capacity. For example, if the number of working chillers are equal to 6 then 5 of them will operate at full load and the last one will operate at partial load condition, and all the 6 chillers operate at the same low evaporation temperature. The automatic diverting valve is switched to direct the outlet of the ice-storage tanks to point $\mathrm{A}$. The two-way valve on $\mathrm{B}-\mathrm{C}$ line is turned on to open the flow from B to C, and the two-way valve on the bypass line is turned off. The refrigeration system must cool the coolant below the freezing temperature of the plain water inside the ice-storage tanks. At the temperature modulating valve some of the chilled coolant that leaves the chiller will mix with some of the warm coolant that leaves the building to obtain the desired supply temperature to the building. The remainder chilled coolant will enter into the icestorage tanks to freeze the water. The exit coolant from the ice-storage tanks will mix at point $\mathrm{A}$ with the remainder warm coolant. The mixed coolant enters into the refrigeration systems to be cooled and the process continues until the end of the charging cycle. A mass balance at the temperature modulating valve yields:

$$
\dot{\mathrm{m}}_{2}+\dot{\mathrm{m}}_{8}=\dot{\mathrm{m}}_{6}
$$

While an energy balance yields:

$$
\dot{\mathrm{m}}_{2} \cdot \mathrm{C}_{\mathrm{c} 2} \cdot \mathrm{T}_{2}+\dot{\mathrm{m}}_{8} \cdot \mathrm{C}_{\mathrm{c} 8} \cdot \mathrm{T}_{8}=\dot{\mathrm{m}}_{6} \cdot \mathrm{C}_{\mathrm{c} 6} \cdot \mathrm{T}_{6}
$$


The mixing process at point A can be represented by the following equations:

$\dot{\mathrm{m}}_{9}+\dot{\mathrm{m}}_{5}=\dot{\mathrm{m}}_{10}$

And:

$\dot{\mathrm{m}}_{9} \cdot \mathrm{C}_{\mathrm{c} 9} \cdot \mathrm{T}_{9}+\dot{\mathrm{m}}_{5} \cdot \mathrm{C}_{\mathrm{c} 5} \cdot \mathrm{T}_{5}=\dot{\mathrm{m}}_{10} \cdot \mathrm{C}_{\mathrm{c} 10} \cdot \mathrm{T}_{10}$

Mass balances at points $\mathrm{D}$ and $\mathrm{B}$ gives :

$\dot{\mathrm{m}}_{2}+\dot{\mathrm{m}}_{3}=\dot{\mathrm{m}}_{1}$

$\dot{\mathrm{m}}_{9}+\dot{\mathrm{m}}_{8}=\dot{\mathrm{m}}_{7}$

The mass flow rate of the water directed to the building, $\mathbf{m}_{6}$, is calculated from :

$$
\dot{\mathrm{m}}_{6}=\frac{\mathrm{Q}_{\mathrm{load}}}{\mathrm{C}_{\text {cav }} \cdot\left(\mathrm{T}_{7}-\mathrm{T}_{6}\right)}
$$

And the mass flow rate of the coolant to each ice-storage tank can be calculated from:

$\dot{\mathrm{m}}_{\mathrm{c}}=\dot{\mathrm{m}}_{3} / \mathrm{N}_{\text {tank }}$ 
The discharge strategy is shown in Figure (3b). At the start of the discharge cycle, the control system sets the refrigeration systems to operate at constant high evaporation temperature and at constant capacity. The working chillers will operate at full load except the last one will operate at partial load condition. The system switches the automatic diverting valve to direct the outlet of the ice-storage tanks to point $\mathrm{C}$, and turn off the two-way valve on B-C line, and turn on the two-way valve on the bypass line. Mixing process to the coolant will occur at point E. The temperature of the coolant at point 11 is greater than the desired supply temperature to the building; therefore, the coolant will divided into two parts, the first passes through the ice-storage tanks and the second part bypass them. The two parts then mixes at the temperature modulating valve to obtain the desired supply temperature to the building. Mass balance at point $\mathrm{E}$ gives:

$$
\dot{\mathrm{m}}_{1}+\dot{\mathrm{m}}_{\text {bypass }}=\dot{\mathrm{m}}_{11}
$$

Energy balance at point E gives:

$$
\dot{\mathrm{m}}_{1} \cdot \mathrm{C}_{\mathrm{c} 1} \cdot \mathrm{T}_{1}+\dot{\mathrm{m}}_{\text {bypass }} \cdot \mathrm{C}_{\mathrm{c} 10} \cdot \mathrm{T}_{10}=\dot{\mathrm{m}}_{11} \cdot \mathrm{C}_{\mathrm{c} 11} \cdot \mathrm{T}_{11}
$$

Figure (3c) illustrates the flow diagram during the conventional operation of the refrigeration systems. Under the partial storage strategy the conventional operation appears only during the on-peak hours when the building load is less than or equal to $\sim 0.897 \mathrm{MW}$ for occasional profile and when equal to $\sim 0.791 \mathrm{MW}$ for normal profile. The normal control of the refrigeration system will be employed in this case.

To complete the mathematical simulation model, the refrigeration capacity required at any time in the charge cycle has to be worked out. The charging process occurs only during the off-peak hours (8 hours). Case (1) with the occasional profile will be used to explain the method of estimating the refrigeration system capacity during the charge cycle and the required number of ice-storage tanks.

First we must estimate the amount of the shifted load, SL, is to be estimated from the on-peak hours, as:

$$
\begin{aligned}
\mathrm{SL}= & {\left[\mathrm{Q}_{\text {load }}\left(\mathrm{hr}_{11}\right)-\mathrm{RSC}\right] * 2+\mathrm{Q}_{\text {load }}\left(\mathrm{hr}_{15}\right)-\mathrm{RSC}+} \\
{\left[\mathrm{Q}_{\text {load }}\left(\mathrm{hr}_{18}\right)-\mathrm{RSC}\right] * 3 } & \\
= & 4.17+0.10+6.26=10.53 \mathrm{MW}-\mathrm{hr}
\end{aligned}
$$


Then, the required number of ice-storage tanks is estimated from:

$$
\mathrm{N}_{\text {tank }}=\frac{\mathrm{SL} * 3600}{\mathrm{SCPT}} \cong 226 \text { tanks }
$$

The storage modules heat loss over the sixteen on-peak hours is estimated as:

$$
\mathrm{L}=\mathrm{Q}_{\text {loss }} * \mathrm{~N}_{\text {tank }} * 16=0.449 \quad \text { MW-hr }
$$

Adding the storage losses to the shifted load yields the total energy to be stored, i.e.:

$$
\mathrm{TSE}=\mathrm{SL}+\mathrm{L}=10.5 \quad \mathrm{MW}-\mathrm{hr}
$$

The number of storage tanks is then corrected to take into consideration the revised value of stored energy. Applying equation (12) with TSE instead of SL gives:

$$
\mathrm{N}_{\text {tank }}=\frac{10.98 * 3600}{168.48}=234.66 \sim 235 \text { tank }
$$

Finally, the above calculations are to be iterated to fix the required number of tanks, in this case the final value was 236 modules. The required refrigeration system capacity during the charging cycle is calculated as follows:

$$
\begin{aligned}
\mathrm{RSC} & =\frac{\mathrm{SL}+\sum_{\mathrm{hr}=21}^{\mathrm{hr}=4} \mathrm{Q}_{\text {load }}(\mathrm{hr})+\mathrm{L}}{\sum_{\mathrm{hr}=21}^{\mathrm{hr}(\mathrm{hr})}+\mathrm{Q}_{\text {loss }} * \mathrm{~N}_{\text {tank }}} \\
& =1.75 \mathrm{MW}
\end{aligned}
$$

The refrigeration system capacity used in the simulation program is equal to $\sim 1.76 \mathrm{MW}$. It is found that the required number of storage tanks is equal to 125 tanks and 204 tanks for case (2) and case (3) respectively and the required refrigeration system capacity is equal to $1.099 \mathrm{MW}$ and $\sim 1.56 \mathrm{MW}$ respectively. For the normal profile the required number of storage tanks is $=321.620 \mathrm{ks}$ and the refrigeration system capacity is 0.543 MW.

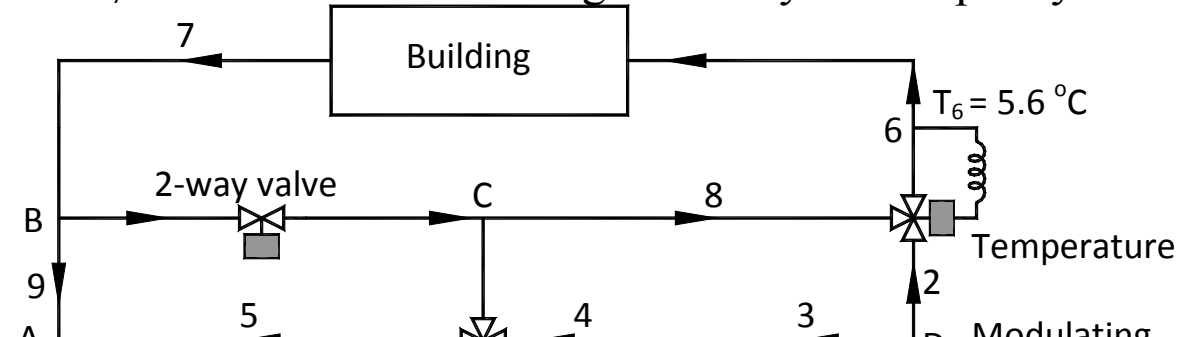




\begin{tabular}{llll} 
Al-Rafidain Engineering & Vol.14 & No.r & 2006 \\
\hline
\end{tabular}

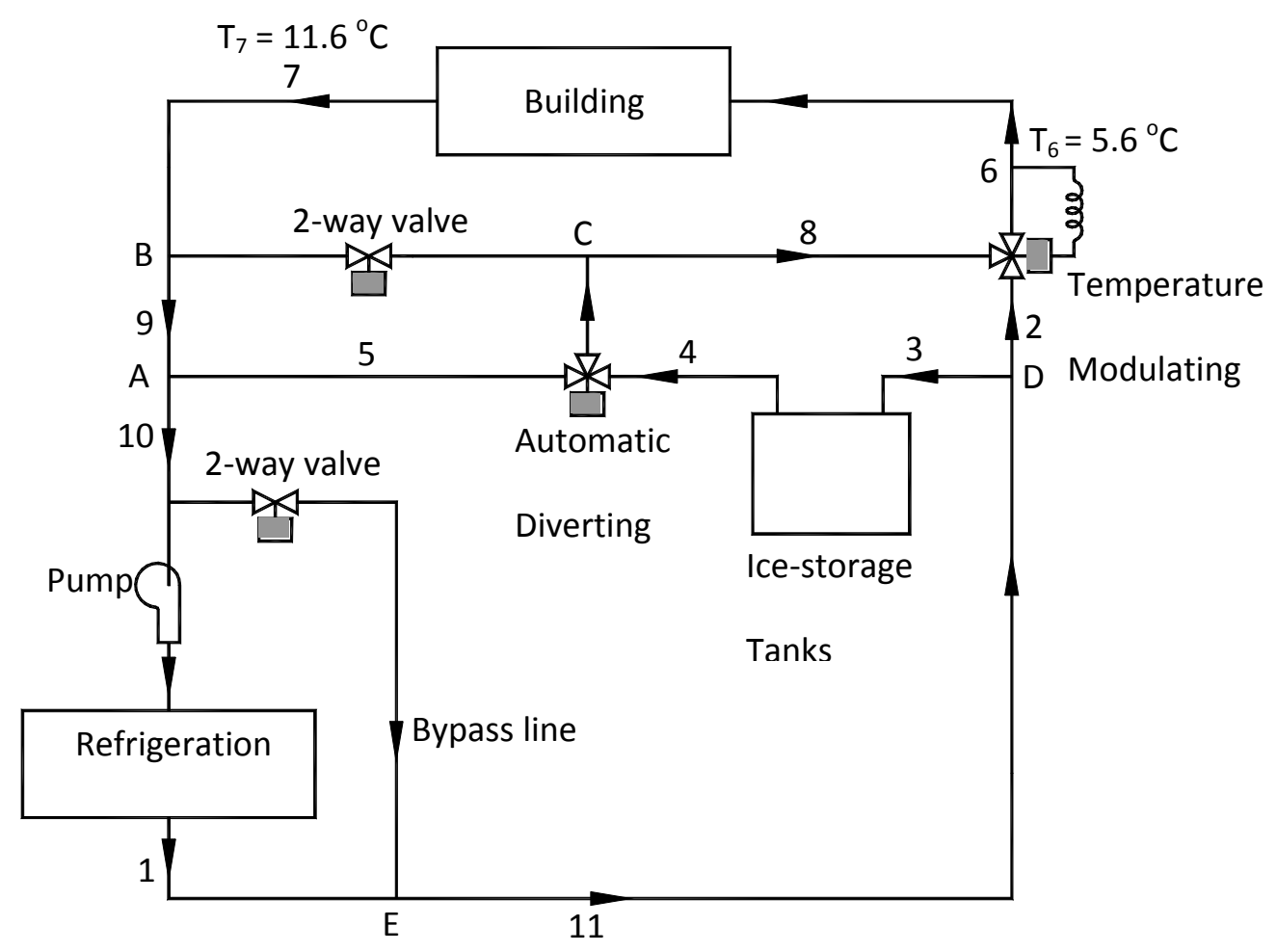

Figure (3b): System operating status during the discharge cycle.

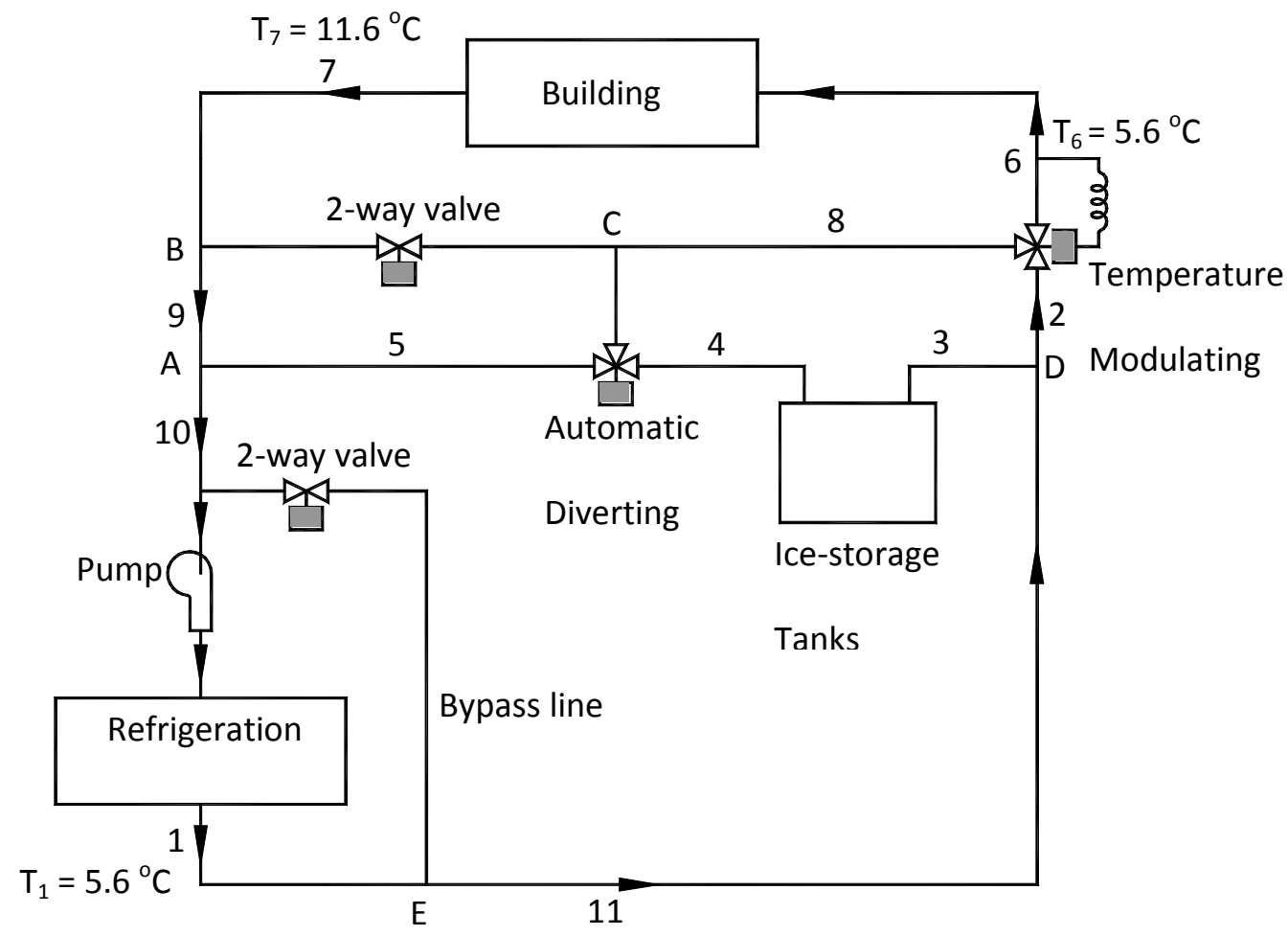

Figure (3c): System operating status under the conventional strategy 


\section{$\underline{\text { Results and Discussion }}$}

The occasional profile results: Under the partial storage strategy the evaporation temperature was held constant at $-6^{\circ} \mathrm{C}$ and $4{ }^{\circ} \mathrm{C}$ during the charge and the discharge cycles respectively. The conventional operation appears only when the building load is less than or equal to $\sim 0.897 \mathrm{MW}$ and, as stated earlier, the exit coolant temperature from the chillers is fixed at $5.6^{\circ} \mathrm{C}$ while the exit coolant temperature from the building is fixed at $11.6^{\circ} \mathrm{C}$. Finally, the evaporation temperature is specified according to the value of the chiller capacity (same as in the conventional strategy).

Figure (4) illustrates the variation of the total power consumption with time. For case(1) and (3) the results indicated that the total power consumption during the discharge cycle is lower than that of the charge cycle, due to the system being working at higher evaporation temperature during the daytime. This causes an increase in COP over that of the night time period. However, for case(2) the opposite occurs due to the system being working at higher capacity during the discharge hours which leads to increasing the number of working chillers to satisfy the load management requirements as will be shown later. For the conventional strategy, the power consumption is high during the period of high price bracket, while for the partial storage strategy it is high during the period of low price bracket. The summation of the total power consumption under the partial storage strategy is greater than that under the conventional strategy by $23.1 \%, 16.4 \%$, and $21.8 \%$ for case (1), case (2), and case (3) respectively. However, the peak power consumption is reduced by $74.5 \%, 39.2 \%$, and $59.7 \%$ respectively. Moreover, $47.2 \%$, $24.1 \%$, and $37.3 \%$ of the consumed power is shifted to the low price period.

The variation of the building load, chiller capacity, rate of stored energy, rate of discharged energy, and the total storage modules heat losses with time for the three cases are shown in Figures (5) to (7) respectively. The 
stored energy is equal to the available energy from the chiller after satisfying the night cooling load. The amount of the shifted load from the on-peak period is equal to $45.2 \%, 24 \%$, and $39.1 \%$ for the three cases respectively. The variation of the ice mass with the time of the day is shown in Figure (8). These profiles follow the variation of the rate of stored energy and the rate of the discharged energy which were explained previously.

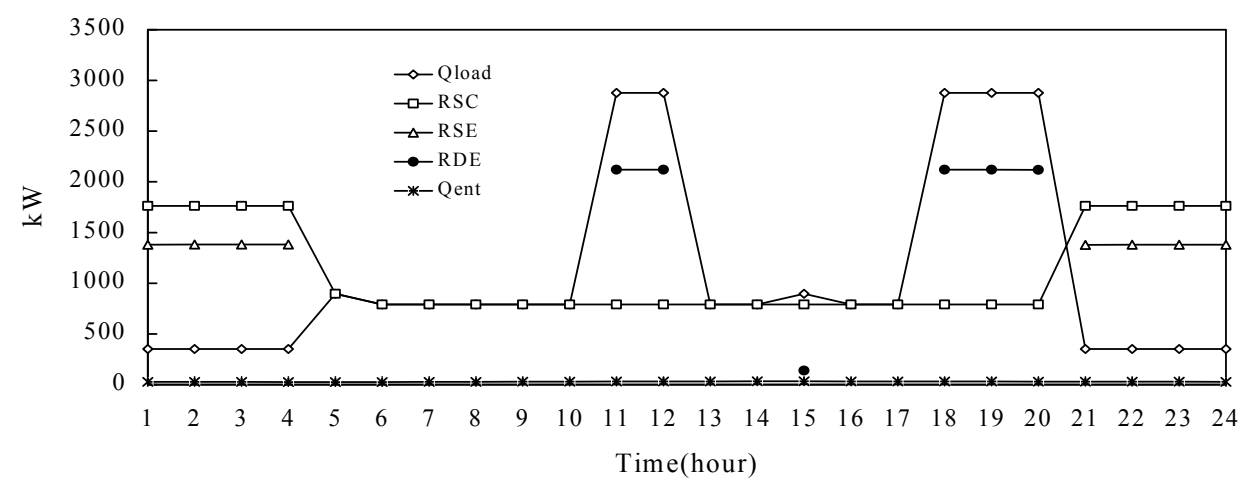

Figure(5): Variation of the building load, chiller capacity, rate of stored energy, rate of discharged energy, and the total tanks heat losses with time.[Occational profile-case(1)].

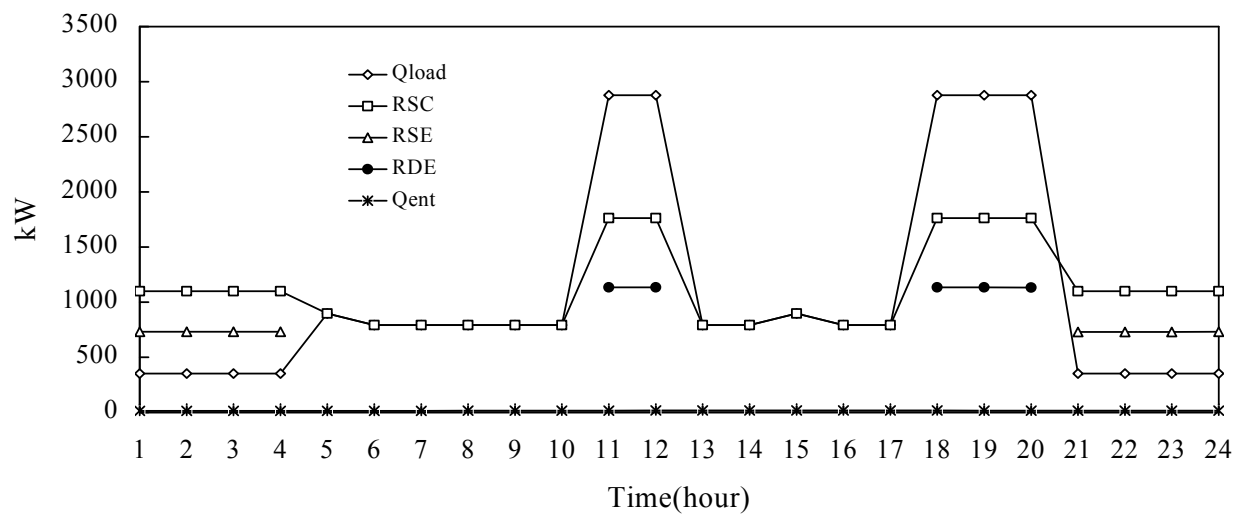

Figure(6): Variation of the building load, chiller capacity, rate of stored energy, rate of discharged energy, and the total tanks heat losses with time.[Occational profile-case(2)]. 


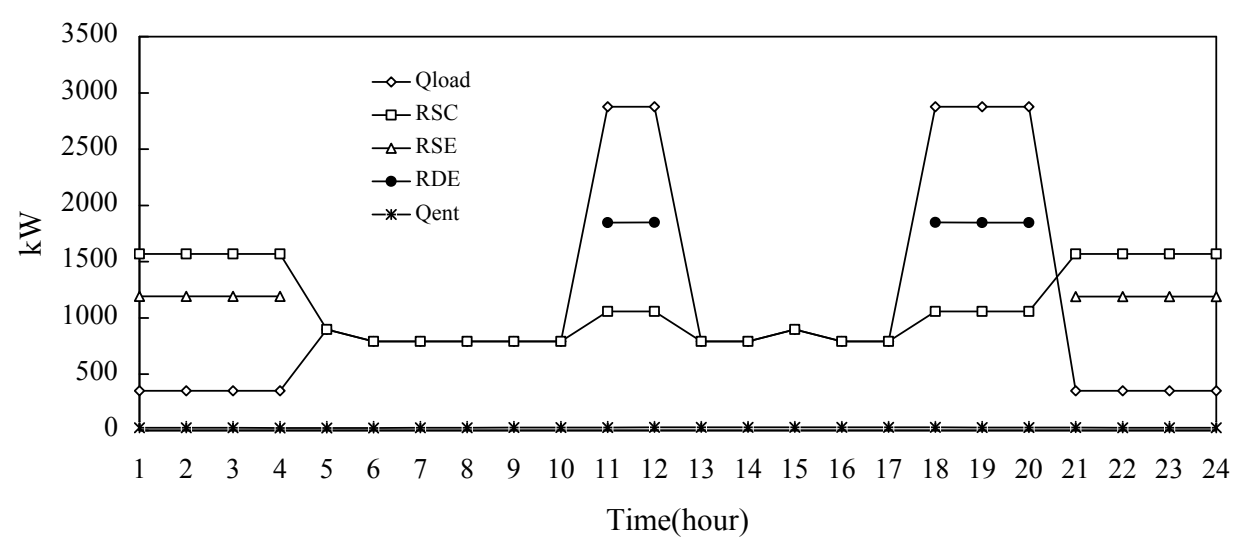

Figure(7):Variation of the building load, chiller capacity, rate of stored energy, rate of discharged energy, and the total tanks heat losses with time.[Occational profile-case(3)].

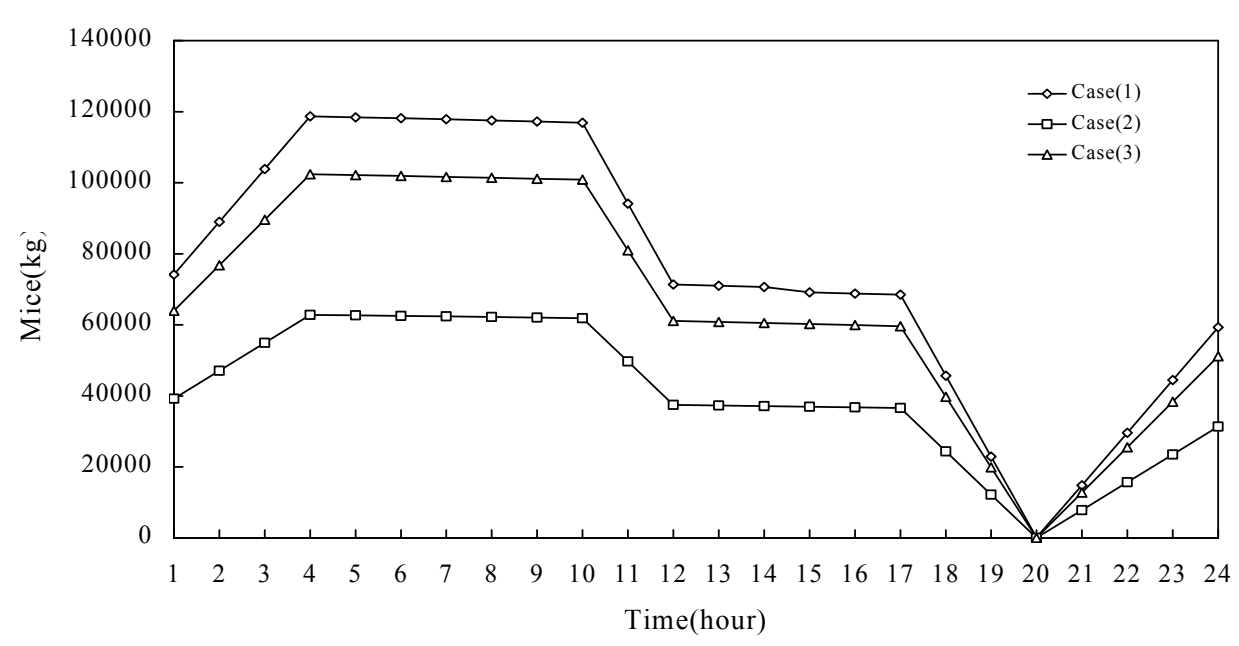

Figure(8): Variation of the stored ice mass with time.[Occational profile].

The amount of the heat loss from the tanks over the 24-hours period is about $6.4 \%$ from the total stored energy for each case. Figure (9) depicts the variation of the number of working chillers with time. For the conventional strategy the number of working chillers increases during the high load on-peak hours, while with the partial storage strategy the number of working chillers increased during the off-peak period which reflects positively on the operating cost as explained previously. 


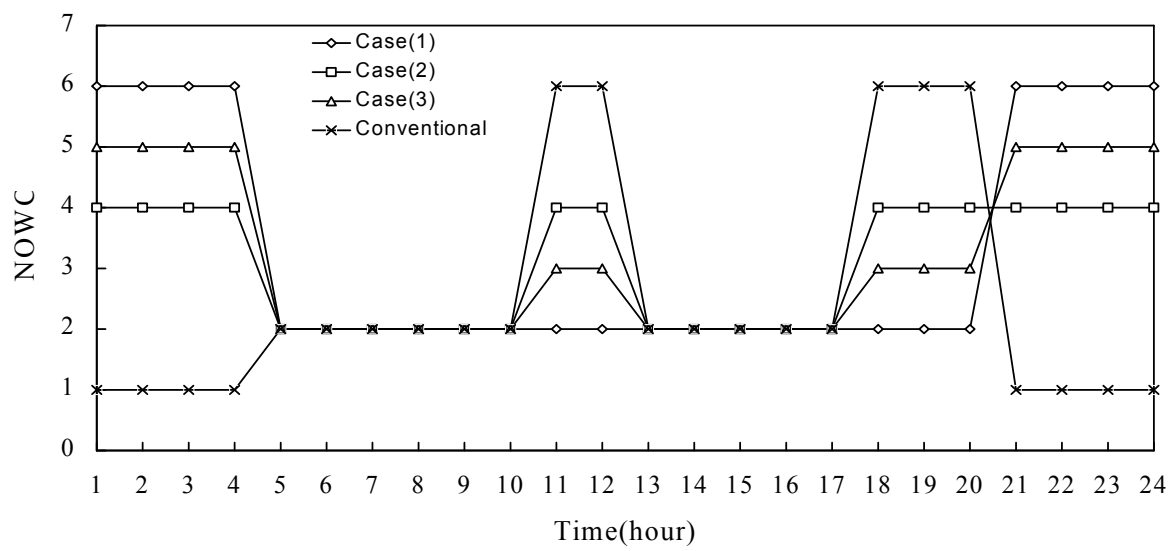

Figure(9):Variation of the number of working chillers with time.[Occational profile]. 
The normal profile results: The same operating strategies and operating conditions are followed here. The conventional operation used with partial storage strategy appears only when the cooling load is equal to $0.791 \mathrm{MW}$. When the cooling load exceeded this value the stored energy is exhausted to satisfy the building load requirements. The variation of the total power consumption with time is shown in Figure (10). For the conventional strategy the power consumption during the hours $5,11,12$ a.m., 3, 6, 7, 8 p.m., (on-peak hours), is greater than those under the partial storage strategy, while the power consumption is high from hour 9 p.m. to 4 a.m., (off-peak hours) under the partial storage strategy.

The summation of the total power consumption under the partial storage strategy is greater than that under the conventional strategy by $12.6 \%$, however, the peak power consumption is reduced by $33.1 \%$, and about $10 \%$ of the consumed power is shifted to the low price period. Figure (11) illustrates the variation of the various heat transfer rates during the charge and the discharge cycles. The amount of the shifted load from the onpeak period is equal to $9.8 \%$. The heat loss from the storage system amounts to $6.4 \%$. Finally, the variation of the stored ice mass and the number of working chillers with time is shown in Figures (12) and (13) respectively.

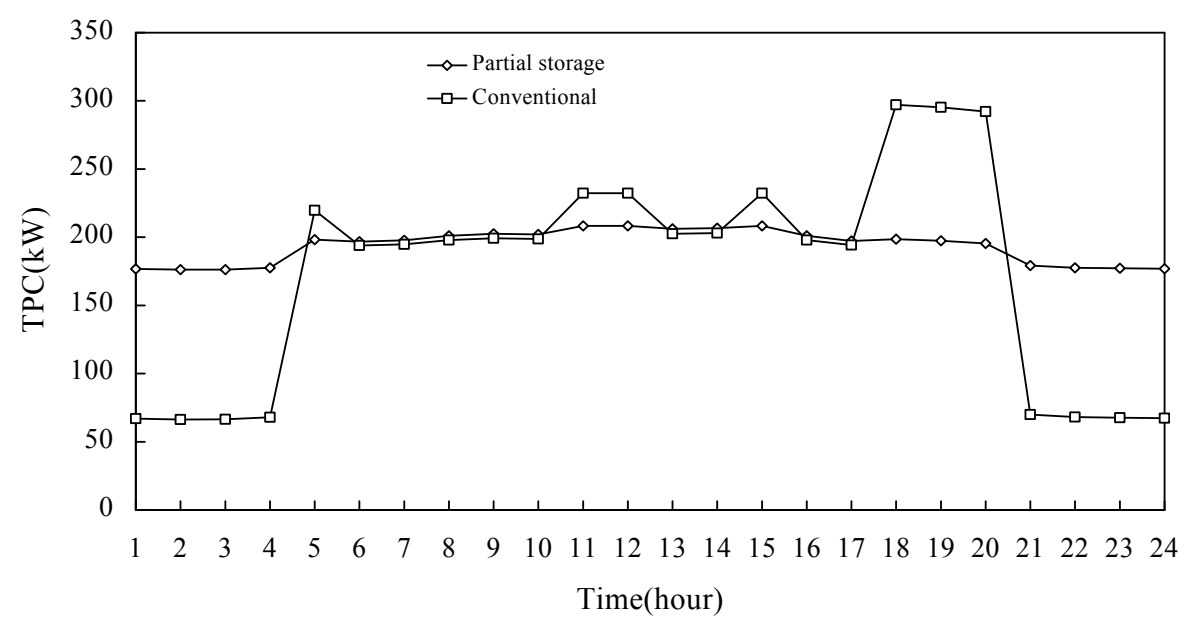

Figure(10): Variation of the total power consumption with time.[Normal

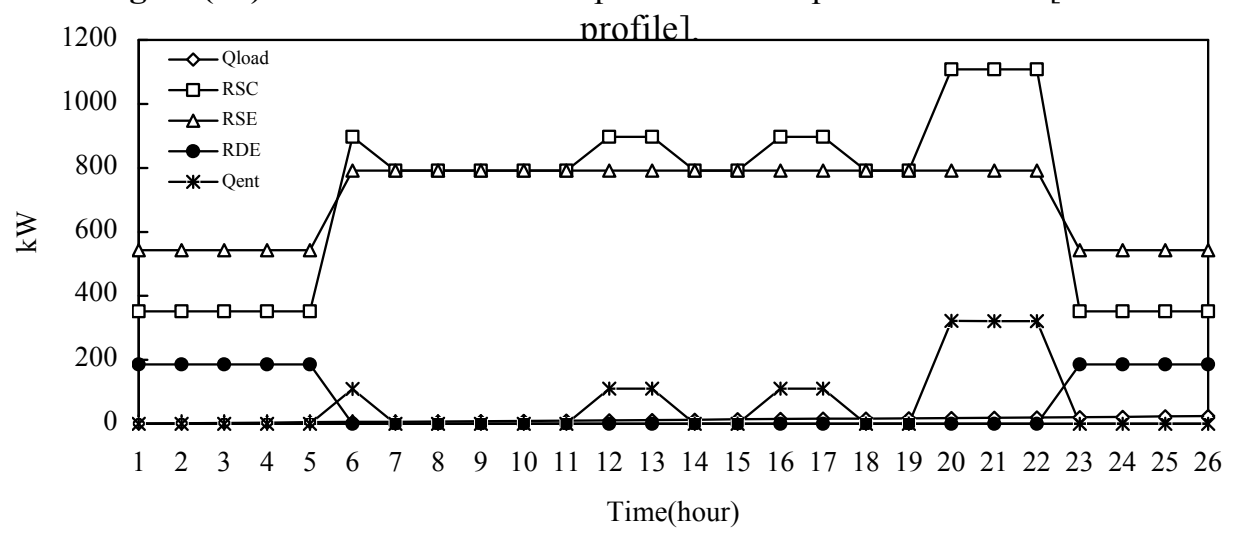

Figure(11):Variation of the building load, chiller capacity, rate of stored energy, rate of discharged energy, and the total tanks heat losses with time.[Normal profile]. 


$\begin{array}{llll}\text { Al-Rafidain Engineering } & \text { Vol.14 } & \text { No.r } & 2006\end{array}$

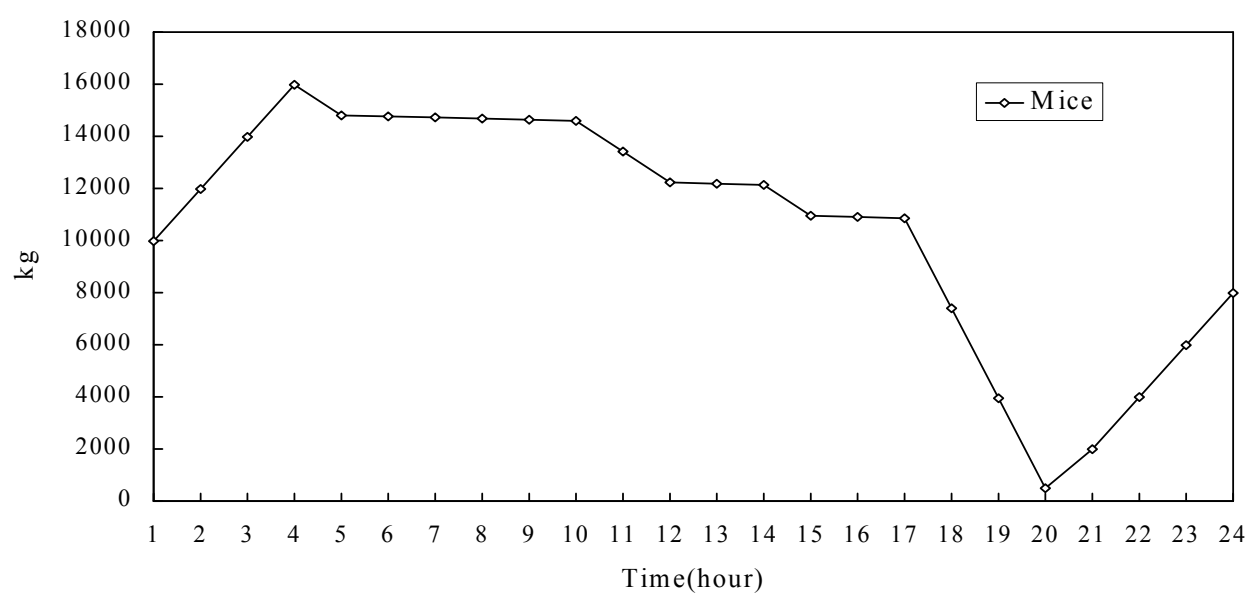

Figure(12): Variation of the stored ice mass with time.[Normal profile].

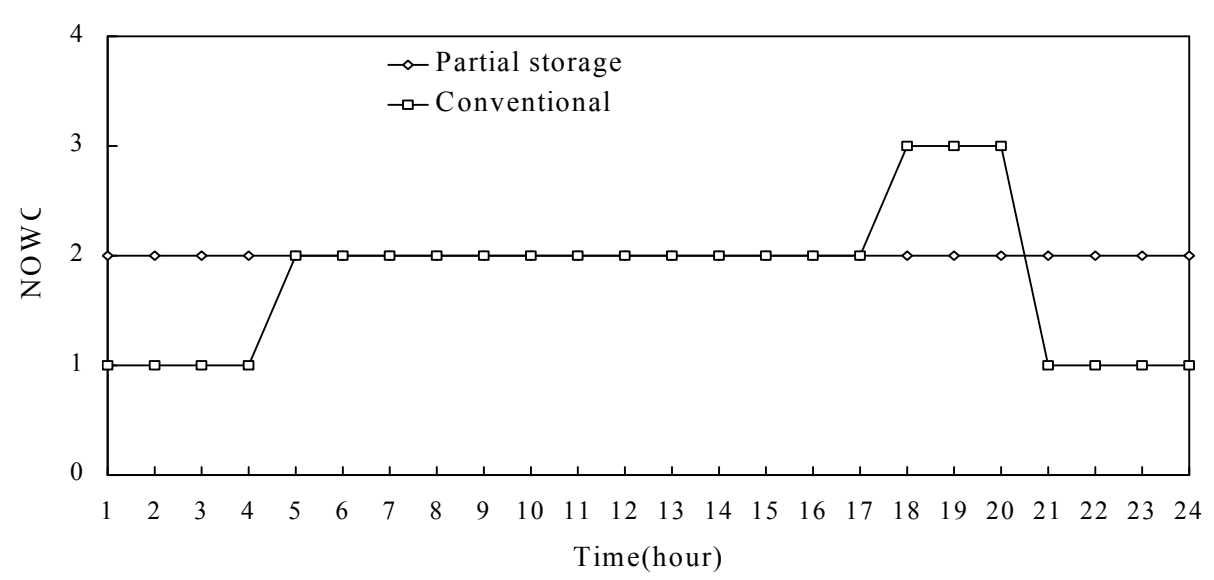

\section{Conclusions:}

Figure(13): Variation of the number of working chillers with time.[Normal

In this paper the method of combining TES units with the refrigeration system serving a large mosque building in Mosul city with two cooling load profiles, namely: the occasional and the normal profiles is illustrated. The system is simulated on the computer and the relevant simulation results are discussed. From the results, it can be concluded that, under the partial storage strategy and for the occasional profile the required system capacity during the off-peak period are $\sim 1.76 \mathrm{MW}, 1.09$ $\mathrm{MW}$, and 1.56 MW for the three cases respectively and the required number of ice-storage tanks are 236, 125, and 204 respectively. For the normal profile, the required system capacity is $0.54 \mathrm{MW}$ and the required number of storage tanks is 32 .

The amount of the shifted load from the on-peak period for the occasional profile is equal to $45.2 \%, 24 \%$, and $39.1 \%$ for the three cases respectively. For occasional profile the peak power consumption is reduced by $74.5 \%, 39.2 \%$, and $59.7 \%$ for the three cases respectively and $47.2 \%, 24.1 \%$, and $37.3 \%$ respectively of the consumed power is shifted to the low price period which will add significantly to the total cost 
reduction. For the normal profile the amount of the shifted load from the on-peak period is equal to $9.8 \%$. The peak power consumption is reduced by $33.1 \%$, and about $10 \%$ of the consumed power is shifted to low price period.

\section{Nomenclature:}

$\mathrm{C}_{\text {cav }}$ Average specific heat of the coolant $\left(\mathrm{kJ} / \mathrm{kg}-{ }^{\circ} \mathrm{C}\right)$.

$\mathrm{C}_{\mathrm{c} 1}, \ldots \ldots ., \mathrm{C}_{\mathrm{c} 11} \quad$ Specific heats of the coolant at the points $1, \ldots \ldots, 11$ respectively $\left(\mathrm{kJ} / \mathrm{kg}-{ }^{\circ} \mathrm{C}\right)$.

hr hour.

L Energy losses from the tanks a long 16 hour (kW-hr).

$\dot{\mathrm{M}}_{\text {bypass }} \quad$ Mass flow rate of the coolant that bypass the refrigeration systems $(\mathrm{kg} / \mathrm{s})$.

$\dot{\mathrm{M}}_{\mathrm{c}} \quad$ Mass flow rate of the coolant inlet to the tank $(\mathrm{kg} / \mathrm{s})$.

$\mathrm{M}_{\text {ice }}$ Total mass of ice in all the tanks in the system $(\mathrm{kg})$.

$\dot{\mathrm{M}}_{1}, \ldots \ldots, \dot{\mathrm{M}}_{11} \quad$ Mass flow rates of the coolant at the points $1, \ldots \ldots, 11$ respectively $(\mathrm{kg} / \mathrm{s})$.

NOWC Number of working chillers.

$\mathrm{N}_{\text {tank }} \quad$ Number of ice-storage tanks.

$\dot{Q}_{\text {ent }} \quad$ Rate of heat transfer into the tanks from the environment (W).

$\mathrm{Q}_{\text {load }}$ Cooling load (kW).

$\mathrm{Q}_{\text {loss }} \quad$ Average value of the losses per tank $(\mathrm{kW})$.

RDE Rate of discharged energy (kW).

RSC Refrigeration system capacity $(\mathrm{kW})$.

RSE Rate of stored energy $(\mathrm{kW})$.

SCPT Storage capacity per tank $(\mathrm{kJ})$.

SL Amount of the shifted load (kW-hr).

TPC Total power consumption of the refrigeration systems $(\mathrm{kW})$.

TSE Total stored energy ( $\mathrm{kW}$ hr).

$\mathrm{T}_{1}, \ldots . ., \mathrm{T}_{11} \quad$ Temperatures of the coolant at the points $1, \ldots \ldots, 11$ respectively $\left({ }^{\circ} \mathrm{C}\right)$. 


\section{References:}

1- " Thermal energy storage strategies for commercial HVAC systems", Pacific gas and electric company report, May 1997.

2- PYEOGCHAN i., Krarti M., and Henze G., " Development of a thermal energy storage model for energy plus", Energy and building, no 36, 2004.

3- " Application of ice storage to air cooled chillers in Johnston county schools", TRANE report, www.trane.com.

4-MacCracken, C.D., "OPAC - All New for the 1990s", ASHRAE Journal, Vol. 32, No. 4, April 1990, PP. 44-46.

5- Henze G., and Krarti M.,"Ice storage systems controls for the reduction of operating cost and energy use", ASRAE transactions 2000, personal communications.

6-Engineering Consult Bureau Internal report, College of engineering, University of Mosul-Iraq, 1999.

7-Rawlings, L. , "Strategies to Optimize Ice Storage", ASHRAE Journal, Vol. 27, No. 5, May 1985, PP. 39-48.

8- Mostafa, W., Kahwaji G., and Al-Ali B.," An Optimum Refrigeration System Controller," Engineering and Technology, Vol. 12-No. 5-1993.

9- Kahwaji G.Y. and Mohammed S.A., "Modeling and design of an Ice storage system", Submitted for publication to the University of Sharjah Science and Technology Journal - Jan. 2005.

10- Kahwaji G.Y. and Mohammed S.A., "Performance of an ice storage assisted air conditioning system", Submitted for publication to the University of Sharjah Science and Technology Journal - Jan. 2005.

11- Mohammed, S.A., "Design and Simulation of Ice-Storage Assisted Air Conditioning Systems in Public Buildings", M. Sc. Thesis, College of Engineering, University of Mosul, 1998.

12-Calmac,"An Introduction to Off-Peak Air Conditioning OPAC for Commercial Applications", Calmac Manufaturing Corporation, Englewood, NJ07631-0710.

13-Thumann, A., "Optimizing HVAC Systems", Published By The Fairmont Press, Inc., 700 Indian Trail, Lilburn, GA30247, 1988. 